\title{
Masjid Sebagai Agen Baznas: Analisa Potensi SDM Ta'mir Masjid di Kabupaten Jepara
}

\author{
M. Husni Arafat*, M. Husni Tamrin**, Aan Zainul \\ Anwar $^{* * *}$, Alex Yusron Al Mufti**** \\ Universitas Islam Nahdlatul Ulama (UNISNU), Jepara \\ Email: mhusniarafat85@gmail.com
}

\begin{abstract}
Islamic teachings, which obliges his people to issue zakat, gives a huge potential even able to make Muslims as a very noble and prosperous people, but in fact the role and function of zakat has not been able to deliver Muslims into a prosperous community. The potential of national zakat as much as 217 bbillion and up to now has not been able to achieve. One of the factors is due to the limitations of zakat agencies so that the distribution of zakat has not been so easily accessed by the muzakki. On the one hand, the existence of mosques scattered throughout the community environment is able to answer upon not reaching the amount of potential acceptance of zakat by making the mosque as the agent of the national zakat agency. This study aims to determine the potential of human resources (HR) and the ability as an agent of zakat acceptance by ta'mir mosque in Jepara regency. This research method uses survey, questioner and in-depth interview (in-depth interview). The results of this research ta'mir mosque majority willing to become Baznas agent in accepting zakat maal but require knowledge, understanding and standardization of zakat management, either manually or on-line real
\end{abstract}

* Dosen Jurusan Hukum Keluarga Islam (Ahwal Syakhshiyyah), Fakultas Syariah dan Hukum, UNISNU, Jepara.

** Dosen Jurusan Manajemen, Fakultas Ekonomi dan Bisnis, UNISNU, Jepara.

*** Dosen Jurusan Ekonomi Islam, Fakultas Ekonomi dan Bisnis, UNISNU, Jepara.

**** Dosen Jurusan Pendidikan Agama Islam, Fakultas Tarbiyah dan Ilmu Kependidikan, UNISNU, Jepara.

ulul albab: Jurnal Studi dan Penelitian Hukum Islam 
Masjid sebagai Agen Baznas ... $\mid 59$

time. In addition, socialization to all levels of society, especially those who have been obliged to issue zakat maal to be channeled to the nearest zakat management organization (mosque).

Keywords: Ta'mir Masjid, Baznas Agency, Zakat Maal, The Potency of Zakah.

\begin{abstract}
Abstrak
Ajaran Islam yang mewajibkan umatnya untuk mengeluarkan zakat memberikan potensi yang sangat besar bahkan mampu menjadikan umat Islam sebagai umat yang sangat mulia dan sejahtera, namun kenyataannya peranan dan fungsi zakat belum mampu menghantarkan umat islam menjadi umat yang sejahtera. Potensi zakat nasional sebanyak 217 trilyun dan hingga saat ini belum mampu tercapai. Salah satu faktor karena keterbatasan lembaga penyalur zakat sehingga penyaluran zakat belum begitu mudah diakses oleh para muzakki. Disatu sisi, keberadaan masjid yang tersebar diseluruh lingkungan masyarakat mampu menjawab atas belum tercapainya jumlah potensi penerimaan zakat dengan menjadikan masjid sebagai agen badan zakat nasional. Penelitian ini bertujuan untuk mengetahui potensi sumber daya manusia (SDM) dan kesanggupan sebagai agen penerimaan zakat oleh ta'mir masjid di Kabupaten Jepara. Metode penelitian ini menggunakan survei, kuesioner dan interview mendalam(in-depth interview). Hasil penelitian ini takmir masjid mayoritas bersedia menjadi agen Baznas dalam menerima zakat maal namun memerlukan pembekalan pengetahuan, pemahaman dan standarisasi pengelolaan zakat, baik secara manual maupun secara online real time. Selain itu, sosialisasi kepada seluruh lapisan masyarakat terutama mereka yang sudah berkewajiban mengeluarkan zakat maal untuk disalurkan kepada organisasi pengelola zakat terdekat (masjid).
\end{abstract}

Kata Kunci: Ta'mir Masjid, Agen Baznas, Zakat Maal, Potensi Zakat.

\title{
Pendahuluan
}

Slam selalu mengajak umatnya untuk hidup sejahtera,
karena islam adalah agama yang rahmatan lil alaminyaitu
agama yang membawa rahmat dan kesejahteraan bagi
seluruh umat manusia sehingga islam tidak hanya 
$60 \mid$ M. Husni Arafat, dkk.

diposisikan sebagai sebuah keyakinan semata, akan tetapi lebih sebagai sebuah pandangan hidup dalam segala hal dengan tujuan mewujudkan maqashidus syariah, yaitu: maslalah. Maslahah adalah mengambil manfaat dan menolak kemahdlaratan untuk memelihara tujuan-tujuan syara'. Sedangkan, tujuan-tujuan syara' yang paling utama dalam hukum islam adalah al-masalih khamsah, yaitu memelihara agama, memelihara jiwa, memelihara akal, memelihara keturunan, dan memelihara harta (As-Syatibi, 1973).

Implementasi dari tujuan tersebut, salah satunya, adalah kesejahteraan sosial dan ekonomi umat Islam. Syariah, pada dasarnya, telah menawarkan beberapa instrumen dalam mewujudkan kesejahteraan sosial-ekonomi seperti dalam pemberdayaan zakat, infaq, sedekah dan wakaf. Sedangkan pemberdayaan zakat tersebut merupakan salah satu instrumen ekonomi Islam yang sangat potensial dalam mengangkat derajat umat Islam.

Ajaran Islam yang mewajibkan umatnya untuk mengeluarkan zakat memberikan potensi yang sangat besar bahkan mampu menjadikan umat islam sebagai umat yang sangat mulia dan sejahtera, namun kenyataannya peranan dan fungsi zakat belum mampu menghantarkan umat islam menjadi umat yang sejahtera. Maka, diperlukan suatu system pengelolaan zakat yang baik. Sistem pengelolaan zakat tersebut tidak hanya dilihat dari faktor tata kelola (manajemen) serta jumlah muzakki dan mustahiqnya saja, melainkan juga bagaimana manfaat zakat ini bisa dirasakan oleh masyarakat untuk kepentingan jangka panjang serta mampu mengangkat kualitas umat Islam (Anwar, 2012), khususnya para fakir miskin dimana golongan tersebut termasuk mustahiq atau golongan yang berhak menerima zakat.

Islam sendiri menganjurkan kepada umatnya untuk menjadi umat yang kuat. Kuat tidak hanya dilihat dari jumlah (quantity) umat Islam, namun kuat juga diukur dengan tingkat

ulul albab: Jurnal Studi dan Penelitian Hukum Islam 
kesejahteraan hidup sehingga akan tercipta makhluk yang berkualitas. Di satu sisi, kemiskinan dan kefakiran seseorang menjadikan seseorang jauh dari hidup yang berkualitas. Sedangkan untuk menjadi manusia yang berkualitas tentu bukanlah hal yang mudah, terlebih mencapai kualitas yang baik (umat Muslim yang kuat) haruslah diberi dan ditanamkan segala hal yang terbaik sejak lahir. Firman Allah Swt:

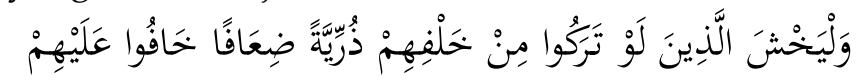

"Dan hendaklah takut kepada Allah orang-orang yang seandainya meninggalkan dibelakang mereka anak-anak yang lemah, yang mereka khawatir terhadap (kesejahteraan) mereka". (QS. Annisa : 9)

Maka, tepat jika zakat dijadikan salah satu instrumen untuk meningkatkan kualitas umat islam melalui peningkatan kesejahteraan dan jaminan kualitas hidup yang lebih baik, minmal rasa aman dan jaminan kesehatan masa depan kepada para fakir miskin dimana dalam kesehariannya tidak terfikirkan untuk kehidupan jangka panjangnya.

Pengelolaan zakat yang professional, akuntabel, mudah dan distribusi yang merata bagi fakir miskin menjadikan sebuah keharusan yang dilaksanakan oleh seluruh pemangku kebijakan, khususnya Negara melalui Badan Amil Zakat Nasional (BAZNAS). Keberadaan BAZNAS sebagai lembaga yang mengelola zakat saat ini perlu melakukan ekspansi dan pengembangan dalam rangka penguatan dan peningkatan penerimaan zakat hingga level masjid. Hal ini karena masjid merupakan tempat ibadah yang langsung bersentuhan dengan seluruh elemen masyarakat. Maka, sudah selayaknya masjid menjadi agen BAZNAS yang penerima dan penyalurkan zakat akan meningkatkan gairah masyarakat untuk menyalurkan zakat dan pemerataan pendistribusiannya dalam rangka meningkatkan taraf hidup masyarakat muslim. 
$62 \mid$ M. Husni Arafat, dkk.

Dengan dijadikannya masjid sebagai agen BAZNAS, tentu menjadikan masjid sebagai lembaga atau badan formal yang diakui Negara dalam melaksanakan pengumpulan zakat. Ini berarti bahwa keberadaan masjid sebagai pengumpul zakat bukan lembaga yang illegal. Hal ini jika mengacu pada pasal 38 Undang-Undang Nomor 23 Tahun 2011 tentang pengelolaan zakat disebutkan bahwa setiap orang dilarang dengan sengaja bertindak selaku amil zakat melakukan pengumpulan, pendistribusian, atau pendayagunaan zakat tanpa izin pejabat yang berwenang. Keberadaan masjid sebagai lembaga resmi pengumpul zakat berpotensi tercapainya potensi zakat di Indonesia yang mencapai Rp. 217 triliun per tahun (Irfan Syauqi Beik, 2013). Sedangkan pada tahun 2015, zakat terhimpun 98,4 milyar (BAZNAS, 2015) atau setara dengan 0,046 persen dari potensi zakat nasional.

Di kabupaten Jepara, total penerimaan zakat melalui BAZNAS Kabupaten Jepara sebanyak 8 milyar (Budiyana, 2016). Penerimaan zakat di Kabupaten Jepara masih belum tercapai potensi penerimaan zakatnya. Potensi penerimaan tersebut akan terus meningkat manakala terdapat kemudahan dalam penyaluran zakat. Diantaranya belum mampu tercapainya potensi penerimaan zakat karena karena keberadaan lembaga atau badan amil zakat kurang tersebar di lingkungan masyarakat. Di satu sisi, di kabupaten Jepara terdapat 876 masjid (BPS, 2014). Jumlah masjid tersebut tersebar di 16 Kecamatan di Kabupaten Jepara. Maka dengan keberadaan masjid sebagai agen Baznas dalam menerima zakat akan mampu tercapai potensi zakat secara maksimal sehingga tercipta kesejahteraan masyarakat muslim.

Untuk mewujudkan masjid sebagai agen penerima zakat Baznas tentu harus di dukung oleh sumber daya manusia (SDM) pengelola masjid atau ta'mir masjid tersebut yang profesional dan akuntabel. SDM yang professional dilator-belakangi oleh beberapa faktor, diantaranya pendidikan, pengalaman, dan 
ketelitian. Hal ini supaya maksud tujuan masjid sebagai penerima zakat masyarakat diatas benar-benar bisa tercapai. Selama ini, peran ta'mir dalam mengelola zakat baru sebatas rutinan atas zakat fitrah atau zakat jiwa yang dikeluarkan selama bulan ramadlan. Maka, tidak menutup kemungkinan ta'mir masjid tersebut mampu mengelola zakat maal yang sifatnya berlaku terus setiap hari atau sebaliknya merasa belum mampu untuk menjadi agen Baznas.

\section{Pengertian Zakat}

Zakat adalah salah satu pilar penting dalam ajaran Islam. Secara etimologis, zakat memiliki arti kata berkembang (anNamaa), mensucikan (at-Thaharatu) dan berkah (al-Barakatu). Sedangkan secara terminologis, zakat mempunyai arti mengeluarkan sebagian harta dengan persyaratan tertentu untuk diberikan kepada kelompok tertentu (Mustahik) dengan persyaratan tertentu pula. (Hafidhuddin, 2002)

Hafidhuddin (2002) juga menyatakan bahwa zakat adalah satu-satunya ibadah yang memiliki petugas khusus untuk mengelolanya, sebagaimana dinyatakan secara eksplisit dalam QS At-Taubah ayat 60 :

"Sesungguhnya zakat-zakat itu, hanyalah untuk orangorang fakir, orang-orang miskin, pengurus-pengurus zakat, para mu'allaf yang dibujuk hatinya, untuk (memerdekakan) budak, orang-orang yang berhutang, untuk jalan Allah dan untuk mereka yuang sedang dalam perjalanan, sebagai suatu ketetapan yang diwajibkan Allah, dan Allah Maha Mengetahui lagi Maha Bijaksana"

Di samping itu, Hafidhuddin (2002) juga mengatakan bahwa pengelolaan zakat melalui institusi amil memiliki beberapa keuntungan, yaitu: (i) lebih sesuai dengan tuntunan syariah, shirah nabawiyyah dan shirah para sahabat serta generasi sesudahnya, (ii) menjamin kepastian dan disiplin pembayar zakat, (iii) untuk menghindari perasaan rendah diri 
$64 \mid$ M. Husni Arafat, dkk.

dari para mustahik apabila mereka berhubungan langsung dengan muzakki, (iv) untuk mencapai efisiensi dan efektivitas pengelolaan dan pendayagunaan zakat, dan (v) sebagai syiar Islam dalam semangat pemerintahan yang Islami. Hafidhuddin (2002)

\section{Badan Amil Zakat Nasional (BAZNAS)}

Baznas atau Badan Amil Zakat Nasional merupakan badan resmi pemerintah satu-satunya yang diberi amanah untuk mengelola zakat berdasarkan Keputusan Presiden RI No. 8 Tahun 2001 memiliki tugas dan fungsi menghimpun dan menyalurkan zakat, infaq, dan sedekah (ZIS) pada tingkat nasional.

Baznas menjalankan 4 (empat) fungsi, yaitu, Perencanaan, Pelaksanaan dan Pengendalian atas pengumpulan, pendistribusian, dan pendayagunaan zakat serta Pelaporan dan pertanggung-jawaban pelaksanaan pengelolaan zakat. (Undang-Undang Republik Indonesia, Nomor 23, Tahun 2011 tentang Pengelolaan Zakat)

\section{Masjid}

Masjid adalah salah satu tempat yang sangat sakral dan sangat penting bagi umat Islam. Keberadan masjid tidak hanya sebagai tempat bersujudnya makhluk kepada tuhannya Allah Swt sang pencipta alam semesta tetapi juga sebagai pusat peningkatan kualitas hidup manusia. Maka tidak heran jikamasjid dianalogikan sebagai representasi derajat hubungan manusia dengan Allah Swt. dan juga antara manusia dengan manusia dimana pengukurannya bergantung kepada taraf iman manusia, makin tinggi iman maka makin makmur suatu masjid ataupun sebaliknya (Mustaming, 2012).

Secara spesifik masjid menurut Institute Manajemen Masjid (Masjid, 2010) memiliki peran dan fungsi sebagai tempat 
beribadah, tempat menuntut ilmu, tempat pembinaan jama'ah, pusat da'wah dan kebudayaan Islam, pusat kaderisasi umat, dan sebagai basis Kebangkitan Umat Islam. Sejak abad 15 Hijriyah umat Islam sekian lama tertidur dan tertinggal dalam percaturan peradaban dunia berusaha untuk bangkit dengan berlandaskan nilai-nilai agamanya. Islam dikaji dan ditelaah dari berbagai aspek, baik ideologi, hukum, ekonomi, politik, budaya, sosial dan lain sebagainya untuk diaplikasikan dan dikembangkan dalam kehidupan riil umat Islam.

Menurut Hassan Rouhani (Konfrontasi, 2015) masjid merupakan pusat penting Islami dan sejak dulu dalam arsitektur Islam tempat suci ini menjadi sentral utama perkotaan dan masyarakat. Asas masjid adalah sebuah tempat untuk kegiatan ibadah, spiritualitas, moral serta pendidikan dan pengajaran. Masjid juga sebagai pusat pemberdayaan ekonomi ummat karena diharapkan masjid juga membangun koperasi, membentuk lembaga amil zakat, infak, sedekah, dan wakaf atau ZISWAF (Saputera, 2011).

Sedangkan, jika mengacu pada masa Rasulullah Muhammad SAW, fungsi masjid Nabawi pada masa tersebutdapat diuraikan antara lain yaitu sebagai (1) tempat melaksanakan ibadah mahdhah seperti shalat wajib, shalat sunnah, sujud, i'tikaf, dan shalat-shalat sunnah yang bersifat insidental seperti shalat Id, shalat gerhana dan sebagainya. Seminggu sekali setiap hari Jum'at dilaksanakan shalat Jum'at dengan didahului dua khutbah untuk membina keimanan dan ketakwaan kaum muslimin. (2) Sebagai pusat pendidikan dan pengajaran Islam. Nabi Muhammad SAW sering menerima wahyu dalam masjid Madinah, dan mengajarkannya pada para sahabat dalam berbagai hal seperti hukum, kemasyarakatan, perundang-undangan dan berbagai ajaran lainnya. Para sahabat nabi melakukan berbagai kegiatan ilmiah di masjid, termasuk mempelajari dan membahas sumber-sumber ajaran Islam. 
$66 \mid$ M. Husni Arafat, dkk.

Di masjid Madinah juga disediakan tempat khusus bagi mereka yang mengkhususkan kegiatannya untuk mendalami ilmu agama yang disebut Ahl al-Shuffah. (3) sebagai pusat informasi Islam. Rasulullah SAW menyampaikan berbagai macam informasi di masjid termasuk menjadi-kannya sebagai tempat bertanya bagi para sahabat (4) Tempat menyelesaikan perkara dan pertikaian, menyelesaikan masalah hukum dan peradilan serta menjadi pusat penyelesaian berbagai problem yang terjadi pada masyarakat, dan (5) Masjid sebagai pusat kegiatan ekonomi. Yang dimaksud kegiatan ekonomi, tidak berarti sebagai pusat perdagangan atau industri, tetapi sebagai pusat untuk melahirkan ide-ide dan sistem ekonomi yang islami, yang melahirkan kemakmuran dan pemerataan pendapatan bagi umat manusia secara adil dan berimbang (Muslim, 2004).

\section{Peran dan Fungsi Masjid}

Pernan dan fungsi masjid yang sangat luas tersebut secara garis besar adalah sebagai tempat penguatan kualitas manusia baik secara horizontal (tempat beribadah) dan penguatan vertical (pusat kesejahteraan umat). Sebagai pusat penguatan umat muslim, keberadan masjid yang didalam pengelolaannya terdapat seseorang atau beberapa orang pengelola masjid yang disebut ta' mir masjid.

Ta'mir masjid yang telah mendapatkan kepercayaan untuk mengelola masjid sesuai dengan fungsinya memegang peran penting dalam memakmurkan masjid. Ta'mir masjid adalah lokomatif atau motor yang menggerakkan umat Islam untuk mengelola masjid, memakmurkan masjid, membina jamaah, membentuk remaja masjid dan menganekaragamkan kegiatan yang dapat dikuti oleh masyarakat sekitar. Masjid yang dikelola secara baik akan membuahkan hasil yang baik pula. Keadaan fisik masjid akan terawat dengan baik. Kegiatankegiatan masjid akan berjalan dengan baik, jamaah pun akan terbina dengan baik dan masjid menjadi makmur (Ayub, 1996).

ulul albab: Jurnal Studi dan Penelitian Hukum Islam 


\section{Ta'mir Masjid}

Ta'mir Masjid adalah organisasi kelembagaan masjid yang terdiri dari beberapa orang dan mempunyai kwajiban memakmurkan masjid (Ponijo, 2013). Selain itu, ta'mir masjid sebenarnya telah bermakna kepengurusan masjid, namun tidak salah jika menyebut "Pengurus Takmir Masjid". Hal ini sesuai dengan firman Allah SWT

"Sesungguhnya orang-orang yang memakmurkan masjid Allah ialahorang-orang yang beriman kepada Allah dan hari akhir, menegakkan shalat, mengeluarkan zakat dan tidak takut kecuali hanya kepada Allah. Karena itu semoga mereka termasuk orang-orang yang mendapat hidayah". (QS. At-Taubah : 18).

Adapun kegiatan yang dilakukan ta'mir masjid meliputi idaroh atau kegiatan administrasi, imaroh atau kegiatan-kegiatan yang mengarah kepada pembinaan jamaah serta ri'ayah, yaitu kegiatan yang berkaitan dengan pembangunan fisik (sarana dan prasarana).

\section{Agen Zakat}

Agen adalah wakil atau perantara. Sedangkan zakat adalah sesuatu yang dikeluarkan atas kewajiban seseorang sebagai orang muslim. Maka, Agen zakat adalah perwakilan lembaga penerima atau pengumpul zakat yang selanjutnya didistribusikan kepada yang berhak menerima zakat (mustahiq).

Ta'mir masjid yang memiliki peran sebagai pelaksana kegiatan - kegiatan pembinaan masyarakat diantaranya adalah mengelola zakat. Kegiatan mengelola zakat ini biasa dilakukan saat bulan puasa.Ta' mir masjid akan bertindak sebagai amil atas zakat fitrah yang dikeluarkan oleh para jama'ah masjid atau masyarakat lainnya. Maka, jika peranannya diperpanjang, ta'mir masjid sebagai agen zakat maal sudah memiliki pengalaman dalam mengelola zakat. 
$68 \mid$ M. Husni Arafat, dkk.

\section{Metode dan Jenis Penelitian}

Metode penelitian dalam penelitian ini menggunakan penelitian jenis kualitatif triangulasi. Triangulasi sendiri adalah metode yang digunakan untuk memeriksa dan menetapkan validitas dengan menganalisa dari berbagai perspektif penelitian yang di teliti. Validitas dalam penelitian kuantitatif dilihat berdasarkan akurasi sebuah alat ukur yaitu instrumen. Validitas dalam penelitian kualitatif mengacu pada apakah temuan penelitian secara akurat mencerminkan situasi dan didukung oleh bukti (Fauziyah, 2015).

Pada jenis penelitian ini, metode yang digunakan adalah Triangulasi Metodologi (Methodological Triangulation). Pemeriksaan konsistensi temuan yang dihasilkan oleh metode pengumpulan data yang berbeda seperti penggabungan metode kualitatif dengan data kuantitatif atau melengkapi data wawancara dengan data observasi. Hasil survei, wawancara dan observasi, dapat dibandingkan untuk melihat apakah hasil temuan sama. Jika kesimpulan dari masing-masing metode yang sama, maka validitas ditegakkan. Observasi dilakukan dengan mengamati kondisi masjid, dimulai dari manajemen ta'mir masjid, proses penerimaan dan penyaluran zakat maal oleh masjid, dan kebutuhan untuk menjadi agen Baznas.Sedangkan survey dilakukan dengan menyebarkan kuesioner ke berbagai masjid yang cakupannya lebih luas.

\section{Potensi Masjid Sebagai Agen Baznas}

Berdasarkan hasil penelitian tentang potensi masjid di Kabupaten Jepara yang berkenan untuk digunakan sebagai agen pengumpul zakat oleh BAZNAS yaitu diperoleh hasil bahwa $71,7 \%$ para ta'mir masjid bersedia sebagai agen Baznas. Sedangkan 28,3\% tidak bersedia. Data tersebut didasarkan atas hasil kuesioner yang tersebar kepada 40 ta'mir masjid yang tersebuar se-Kabupaten Jepara baik masjid perkotaan, pedesaan maupun masjid institusi. Dari 40 kuesioner tersebut diperoleh 
data bahwa 39 dari 40 ta'mir masjid tersebut mengisi kolom berdasarkan pertanyaan potensi masjid.

Data tersebut diperkuat dengan hasil hasil wawancara mendalam kepada 10 ta'mir masjid yang menerima zakat maal dan diperoleh keterangan bahwa mereka bersedia menjadi agen pengumpul zakat Baznas jika Baznas secara kelembagaan menunjuknya. Hal itu juga didukung oleh beberapa pengurus masjid yang pernah mengikuti pelatihan manajemen pengelolaan zakat yang dilakukan oleh Baznas, sehingga tinggal tindak lanjut dari pelatihan tersebut.

Sedangkan pendapat lain yang tidak bersedia menjadi agen Baznas diperoleh informasi bahwa masjid yang digunakan sebagai agen Baznas perlu dipertimbangkan oleh semua pengurus masjid. Pendapat ta'mir yang lain karena menyangkut kepercayaan kepada Baznas. Hal itu karena lemahnya pemahaman tentang Baznas dan masih kurangnya sosialisasi dari Baznas.

\section{Potensi Sumberdaya Manusia (SDM) ta'mir masjid dalam pengelolaan zakat}

Potensi sumberdaya manusia ini diukur dengan pendekatan kebiasaan atau tindakan dalam mengelola zakat yang disalurkan melalui masjid yang selama ini oleh para responden alami. Kuesioner tersebar kepada 40 ta'mir masjid yang tersebuar se-Kabupaten Jepara baik masjid perkotaan, pedesaan maupun masjid institusi. Hasilnya didapat 37.5\% ta'mir masjid dalam melakukan pengelolaan zakat maal mencatat nama orang yang berzakat (muzakki) dalam buku serta merekapitulasi penerimaan zakat. Sisanya $62.5 \%$ tidak mencatat nama orang yang berzakat dan tidak merekapitulasi.

Data diatas setelah didalami dalam wawancara, mayoritas ta'mir masjid tidak mencatat dan merekapitulasi karena ta'mir masjid tidak mendapat pendapatan, baik untuk masjid maupun untuk ta'mir. Selain itu, dana zakat yang 
$70 \mid$ M. Husni Arafat, dkk.

diperoleh langsung oleh masyarakat langsung disalurkan secepatnya dan tidak tersisa karena sifat ta'mir masjid dalam menerima zakat maal sifatnya membantu menunaikan kewajiban muzakki. Sehingga laporan penerimaan dan penyaluran zakat maal tidak terdapat dalam buku laporan masjid.

Selain itu, diperoleh data ta'mir masjid yang memberi tanda bukti penerimaan zakat oleh muzakki masih sangat rendah, yaitu sebanyak $27.5 \%$. Bagi sebagian ta'mir, tanda bukti dituangkan di dalam surat pemberitahuan atau surat keterangan mengeluarkan zakat dan keterangan dalam lampiran berisi informasi sejumlah uang yang di berikan atau dizakatkan. Hal ini dilakukan sebagai bukti informasi bahwa muzakki telah melakukan zakat maal.

Sedangkan $72,5 \%$ ta'mir masjid yang menerima zakat tidak memberikan tanda bukti. Minimnya pengelolaan manajemen zakat oleh ta'mir ini karena dalam mengelola zakat mereka berasumsi hanya sebagai perantara dan tidak mendapatkan pendapatan, maka sosialisasi dan dakwah tentang zakat maal pada masyarakat, terutama pada jamaah masjid masih minim dilakukan, hal ini karena ta'mir masjid tidak semuanya memahami zakat maal.Juga tidak adanya standarisasi model oleh pemerintah, sekalipun sebagian ta'mir pernah mengikuti pelatihan

\section{Kesimpulan}

Tingginya kemauan para ta'mir masjid dalam turut serta mengelola zakat maal berbanding terbalik dengan kemampuan sumberdaya yang ada. Hal ini menjadi potensi untuk membangkitkan gerakan zakat sebagai pilar kekuatan ekonomi syariah berbasis masjid sekaligus menjadi tantangan bagi Baznas dalam melakukan pembinaan pengelolaan zakat yang professional. 
Takmir masjid yang mayoritas bersedia menjadi agen Baznas dalam menerima zakat maal memerlukan pengetahuan, pemahaman dan standarisasi pengelolaan zakat, baik secara manual maupun secara on-line real time.Selain itu, sosialisasi kepada seluruh lapisan masyarakat terutama mereka yang sudah berkewajiban mengeluarkan zakat maal untuk disalurkan kepada organisasi pengelola zakat terdekat.

Maka, Potensi zakat yang sangat besar ini jika kelola dengan maksimal, sistematis, praktis, efisien dan akuntabelakan mampu meningkatkan jumlah penerimaan zakat karena penyaluran zakat oleh masyarakat semakin mudah sehingga perolehan zakat mampu mengurangi kesenjangan ekonomi masyarakat dan meningkatkan kesejahteraan masyarakat miskin.

\section{Daftar Pustaka}

Anwar, A. Z. (2012). Zakat dan Kesejahteraan Guru Agama. Jurnal Dinamika Ekonomi dan Bisnis, 2.

As-Syatibi, A. I. (1973). Al-Muwafaqot fi Ushul as-Syariah. Beirut: Dar al-Maarif.

Ayub, M. E. (1996). Manajemen Masjid. Jakarta: Gema Insani Press.

BAZNAS. (2015). Penerimaan dan Penyaluran Tahun 2015.

Jakarta: BAZNAS.

BPS, J. (2014). Table IV.4.2 Banyaknya Tempat Ibadah Menurut

Prasarananya di Kabupaten Jepara 2014. Jepara: BPS

Kabupaten Jepara.

Budiyana, S. (2016, Januari 16). BAZNAS JEPARA HIMPUN

ZAKAT TERBANYAK DI JATENG . Retrieved from Situs

Resmi Pemerintah Provinsi Jawa Tengah:

http://www.jatengprov.go.id/id/newsroom/baznas-

jepara-himpun-zakat-terbanyak-di-jateng

Hafidhuddin, D. (2002). Zakat dalam Perekonomian Modern.

Jakarta: Gema Insani Press. 
$72 \mid$ M. Husni Arafat, dkk.

Irfan Syauqi Beik, L. D. (2013). Optimization of Zakat Instrument in Indonesia's Poverty Alleviation. Retrieved from Situs The Support for Economic Analysis Development in Indonesia:

http://www.seadiproject.com/0_repository/Session $\% 203$ C\%20-\%20Irfan\%20Syauqi\%20Beik\%281\%29.pdf

Konfrontasi. (2015, Agustus 20). Hassan Rouhani: Masjid Pelopor Kebangkitan Revolusi Iran. Retrieved 3 28, 2016, from http://www.konfrontasi.com/content/khazanah/hassanrouhani-masjid-pelopor-kebangkitan-revolusi-iran

Masjid, I. M. (2010). FUNGSI DAN PERAN MASJID. Retrieved from Situs Masjid Raya Villa Inti Persada: http://www.masjidrayavip.org/index.php?option=com_c ontent\&view=article\&id=125:fungsi-dan-peranmasjid\&catid=45:artikel-islam\&Itemid=67

Muslim, A. (2004, 12). Manajemen Pengelolaan Masjid. Aplikasia, 105-114.

Mustaming, S. (2012, 2 6). FUNGSI MASJID DAN PERANANNYA SEBAGAI PUSAT IBADAH DAN PEMBINAAN UMAT. Retrieved 3 28, 2016, from Website Kemenag Sultra: http://sultra.kemenag.go.id/file/file/Tulisan/zeam132853 4716.pdf

Ponijo. (2013, Januari 15). PERAN DAN FUNGSI TAKMIR $M A S J I D$. Retrieved from Kementrian Agama Bantul: http://bantul.kemenag.go.id/kemenag/artikel-2/121peran-dan-fungsi-takmir-masjid.html

Saputera, A. (2011). Mari Kita Berdayakan Masjid. Retrieved 3 28, 2016, from Kantor Kementrian Agama Provinsi Riau: http://riau1.kemenag.go.id/index.php?a=artikel\&id=521 